

\title{
The makhana value chain and the fast emergence of branding in food retail: Evidence from Bihar (India)
}

Minten, Bart and Singh, K.M. and Sutradhar, Rajib

1 January 2010

Online at https://mpra.ub.uni-muenchen.de/54344/

MPRA Paper No. 54344, posted 13 Mar 2014 14:33 UTC 
The makhana value chain and the fast emergence of branding in food retail: Evidence from Bihar (India)

\author{
January 2010 \\ Prepared by: \\ Bart Minten \\ IFPRI, New Delhi, India \\ K.M. Singh \\ ICAR, Patna, India \\ Rajib Sutradhar \\ JNU, New Delhi, India
}

This study was financed by IFAD and NAIP as part of a support program for the implementation of the National Agricultural Innovation Project (NAIP) in India. 


\title{
The makhana value chain and the fast emergence of branding in food retail: \\ Evidence from Bihar (India)
}

\author{
Bart Minten \\ IFPRI, New Delhi, India \\ K.M. Singh \\ ICAR, Patna, India \\ Rajib Sutradhar \\ JNU, New Delhi, India
}

\begin{abstract}
Brands are rapidly emerging in food retail in Asia. However, it is not well understood what impact they have in these food markets. In a detailed case study of makhana in Bihar, one of the poorest states in India, we see the fast emergence - a doubling over five years leading to a share of 50\% in total trade - of more expensive packaged and branded products. Two types of brands can be distinguished. Low-costs brands focus exclusively on attractive glossy packing with little consideration for quality. Investments, but profits as well, are small. The high-cost brands pay attention to quality beyond packing, invest in advertisements and promotion, explore options for value-addition, and employ specialized salesmen. We find that there are little direct benefits to the farmers from the emergence of these brands. However, farmers might benefit indirectly because of the expanding product demand.
\end{abstract}




\section{Executive Summary}

Introduction. As part of the National Agricultural Innovation Project (NAIP), a makhana value chain study was organized in Bihar, in collaboration between the Indian Council of Agricultural Research (ICAR) in Patna, the International Fund for Agricultural Development (IFAD) and the

International Food Policy Research Institute (IFPRI), as makhana is one of the core crops that the NAIP project in Bihar is focusing on. Primary surveys were fielded with producers, traders, processors, and retailers in 2009 and 2010 on the rural-urban makhana value chain in Bihar, more in particular from the disadvantaged districts part of the NAIP project (Darbhanga) to urban consumers in Patna. The most salient findings are presented below.

Upstream. First, the average number of ponds cultivated by a makhana cultivator is 2 . While almost half of the farmers only cultivate makhana in one pond, $13 \%$ of the households reported to cultivate more than 3 ponds. The average pond area cultivated per household is 4.8 acres. The average production per household in 2009 was 3.1 tons or about $635 \mathrm{kgs}$ per acre. Second, 27\% of the producers evaluated that the quality of seeds deteriorated during drying. Of these, all believed that the quality of pop would have been better if processed earlier. More than a quarter of the producers thus seemingly suffered losses because of late processing. Third, almost all the respondents agree with the statement that you have to be a family of the secretary of the fisherman's cooperative society as to be able to obtain a lease to a government pond. This is important given that rates for these government ponds are often leased much below market rates. An average lease is for 3 years but the majority of the farmers agree that in the case that leases are longer, makhana production would increase because of more investments in the ponds. Fourth, the average production of makhana seeds per pond was about $18 \%$ lower than the expected harvest level during the cultivation period, possibly driven by incidences of floods and droughts as $12 \%$ of ponds were reported to have suffered from floods and another $12 \%$ from droughts. Improved technology adoption is happening as transplanting is now widely used and more than three-quarters of the cultivators indicate that they practice transplanting of the makhana seedlings (in contrast with broadcasting). Fifth, the NAIP project, through the Research Centre for Makhana, is heavily involved in not only improving makhana cultivation but also to extend better alternative income generating activities related to the pond as these can be 
important for the livelihoods of these farmers. Almost $40 \%$ of the makhana cultivators indicate that they also cultivate fish on top of makhana in their ponds. $8 \%$ reported that they grow fruit trees on the boundaries of the makhana ponds. Sixth, an average transaction at the farm level concerns 1.2 tons of makhana sold for a total value of 62,458 Rs (about 1,400 USD). Most of the makhana sold by farmers is marketed under the form of makhana seeds (55\% of the transactions). Most of the sales of makhana happen in a short-time period and it seems that few farmers store makhana as to benefit from the (potentially) higher prices that might be offered in the off-season. In contrast with conventional wisdom, input advances are not very important as in only $3 \%$ of the transactions, input advances were reported to have been given by the buyer of the produce. Despite our efforts to field our surveys in areas where the processing company, Shakti Sudha Industries, were active, only $0.3 \%$ of the transactions were reported to have been done with them.

Midstream. First, 96\% of the interviewed wholesalers report that they are currently selling branded and packed products. Branded products now account for almost half of their total sales. This compares to only $23 \%$ five years ago. Second, wholesalers involved in low-cost brands estimate that if the products that were in the bags were sold loose, they would only be able to obtain a price that is on average 15 Rs lower than when bagged. However, some wholesalers indicated that these products were not comparable as the quality of products that go in the branded bags is low and could not be sold loose. Third, despite a large number of interactions with the high-cost brand, Sudha Shakti Industries, as well as with key informants in several of their supposed production areas, only a handful of people could be identified that had direct linkages with the company. It thus seems that their direct procurement model has (mostly) fallen apart in recent years (and they might procure part of their products from traders).

Downstream. First, quality is rewarded in retail markets and the price results show that the lava quality (the highest pop quality) is rewarded with a premium of between $7 \%$ and $11 \%$ in the market place, compared to a mixed quality. Second, significant rewards further exist to branding and packing in retail markets. Packaged products are sold at prices that are $9 \%$ higher and branding adds another $9 \%$ on top of this. Third, the high-cost brand has been successful in opening new markets that did not exist before. Because of the increasing product demand, it is thus important such initiatives are further encouraged. 
The value chain as a whole. Farmers in production areas receive about $55 \%$ of the final retail price in Patna, in the case that makhana is sold loose. As there are no benefits to the farmer of the branding process, this share declines to $50 \%$ in the case of the final price for branded products. In both cases, farmers are thus the agent in the value chain that gets most of the rewards, reflecting also most of his effort for the product. The retail margin is the second most important component in the final price, accounting for $19 \%$ and $22 \%$ in the final retail price of loose and branded products respectively. Processors and urban wholesalers count for equal shares in the final retail price.

Way forward. The research indicates to several policy implications. First, it might indicate the importance of regulatory institutions and effective implementations of those as well as independent certification mechanisms. Several claims done by branding and packing institutions in Bihar are clearly false, i.e. claims are made about export quality while no export quality grades exist; claims are made about approval by research organizations while no such approvals exist; claims are made by the largest branding company on backward linkages while few of such backward linkages exist in practice. The lack of a consumer protection body or any effective regulations in this area leads thus to mis-information of consumers. Second, there are major differences with branding practices in other sectors and countries. No information on the manufacturers is available on the packing of the branding companies implying that companies are not accountable for their products given consumers can not trace back deficient products in the case of defaults. We also find that the quality of branded products, especially for the low-cost brands, is often lower than loose products in these transitional markets. In contrast with regular branding practices, a significant number of brands thus try to hide bad quality inside. Brands in this setting in India thus seemingly have little function except the packing function and signal little credible information to the consumer on other characteristics of the product. While there is little role for the public sector on this, it seems possible that most of these branding practices might disappear over time as consumers become more demanding and informed. Third, no improved varieties of makhana are currently available and the Indian research institute has only recently tried to set up research as to develop improved makhana varieties. Given the important market opportunities that exist and given that makhana is mostly grown by poor and vulnerable households in flood-prone production areas, there seems to be an important positive, and propoor, return to public investments in the development of improved varieties for pond cultivation. 
Fourth, due to the increased demand, makhana cultivation has endogenously diffused to flooded ricefields in the off-season. This might involve important new opportunities for increased production and seasonal income smoothening for rice farmers situated in these flooded areas. As most research has until now focused on pond cultivation, it thus seems important to better understand these systems and develop improved technologies for these types of production environments taking into account their specific constraints. Fifth, leasing arrangements seem to be hampered by important governance problems and the implementation of better auctions systems and longer leases seem called for as to ensure transparency in the allocations of these leases as well as to ensure better investments because of more secure property rights towards higher productivity of the ponds. 


\section{Introduction}

Significant changes are happening in food and agricultural markets in developing countries. The observed changes in Asia concern most importantly the emergence of modern retail in food retail (Reardon et al., 2003) and the increased consumption of high-value agricultural products (Gulati et al., 2007; Delgado et al., 2008). The rapid changes in these markets has led to a large body of research as to better try to understand the impacts of these changes on producers, consumers, and on the food system as a whole (e.g. Reardon et al, 2010; Pingali, 2007; Swinnen and Vandeplas, 2010; Maertens and Swinnen, 2009).

One of the changes in food systems that has recently been documented is the decline of the sales of loose products and the rapid emergence of branded products in food retail in Asia (Minten et al., 2011). For example, the sales of branded rice in traditional markets in Beijing increased by $8 \%$ over the course of five years. Given that modern retail has grown at $23 \%$ over the same period (Reardon et al., 2010) and given that modern retail almost exclusively sells branded products, the effective importance of brands has even grown more. Similar patterns are seen in other countries in Asia. In a study in Delhi, it was shown that $31 \%, 70 \%$, and $78 \%$ of all rice, wheat atta, and mustard oil sold by traditional retailers was branded (Minten et al., 2010). This increasing sales of branded food products is assumed to be an important vehicle to add value to an agricultural product and might have important impacts on consumer and producer welfare (Berges-Sennou et al., 2004). It might have especially a lot of appeal for market development in developing countries (e.g. Anholt, 2005).

While these branded products in developing countries are emerging rapidly, few studies have however looked empirically at how this branding works in domestic markets of developing countries, what the effects are in local retail markets, who is selling and buying these products, who benefits from the branding, and what the effect is on producers. The available studies on branding in developing countries have looked at the switch from manufactured labels to private retail labels, often linked with the emergence of modern retail (e.g. Reardon et al., 2004) or at the effects of brands for export markets in developed countries (e.g. Ponte, 2002). However, there 
are more dynamic changes going on in these markets on top of linkages with modern retail that researchers in agricultural market development have not yet looked at.

We present here the case study of makhana in Bihar, one of the poorest states in India. Makhana, or gorgon nut, is an interesting product as it is almost exclusively commercialized in this state and branding and packing for this crop was not started until recently. It is thus a unique case study on the development of brands in poor settings and its impact on the value chain. We find that branding has diffused rapidly in this market. In a five year period, branded products for this product increased from $25 \%$ to $50 \%$ of the total market. These branded products are sold at significantly higher prices than loose products. Two types of brands can be distinguished, i.e. low-cost and high-cost brands. Low-costs brands focus exclusively on attractive glossy packing with little consideration for quality. Investments, but profits as well, are small. The high-cost brands pay attention to quality beyond packing, invest in advertisements and promotion, explore options for value-addition, and employ specialized salesmen. Despite different claims by the high-cost brands, there are little direct benefits to the farmers from the emergence of these brands. However, farmers might benefit indirectly because of the expanding product demand.

The contributions to the literature are several. First, this is the first study that documents based on survey results the fast emergence of brands in food retail in India. Second, a typology of brands in such developing markets is made. We show that branding practices are often misleading for the consumer by most of the brands. Third, we implement a unique survey set-up where surveys were fielded for all agents in the value chain. By using such a methodology, we are able to document where costs and benefits of the emergence of brands occur.

The structure of the paper is as follows. In Section 2, we present a conceptual framework as to understand the potential impact of the emergence of branding in food markets. Section 3 provides some background information on the product studied. In Section 4, the data collection methodology is discussed as well as some descriptive statistics. Results on the prevalence of branding and packing are presented in Section 5. Section 6 analyzes the market structure of the makhana sector. Section 7 then looks at the rewards to branding in the market place. In Section 8 , we look at the effect of branding on producers. We finish with conclusions and implications in Section 9. 


\section{Conceptual framework}

Various drivers are changing food demand in most developing countries. These drivers include, most importantly, (1) urbanization (a larger share of the population in developing countries is living in urban centers; given that population growth in these countries is often high, a rapid increase in the urban population overall is usually seen); (2) income growth (an important increase in average incomes and a reduction in poverty levels has been seen in a number of developing countries in recent years); (3) changing lifestyle and female participation in the workplace (women have traditionally taken care of agricultural production and/or food preparation, but as they are increasingly entering into the urban labor force, they often have less time to spend on these activities); and (4) increasing access to better technologies (these include, at the household level, the spread of refrigerators, microwave ovens, and gas stoves, which allow for the use of different foods and food preparation methods, and at the industry level, access to better food packaging technology—with the rise of Tetra Pak, for example, which has made packaged milk and juices available in mass markets).

These changes have led consumers in developing countries to demand a different food basket: (1) the quantity, per person and overall, that is demanded from urban food markets is increasing faster than in rural areas; (2) the composition of the food basket is different, as better-off consumers often shift away from grains and consume relatively more high-value products such as fruits and vegetables, dairy products, meat, and fish, ${ }^{1}$ as well as more processed food for convenience; (3) there is a demand for more choices per product and a greater variety of food products in general; and (4) consumers in developing countries are also increasingly concerned about quality and safety issues with regard to their food, especially as safety issues tend to be more correlated with nonstaple foods.

The changing requirements of consumers lead to a restructuring of food supply chains. The final food supply chain arrangements are, however, shaped not only by these demand factors. Conditioning factors such as geography, ${ }^{2}$ the population structure, ${ }^{3}$ the structure of the financial

\footnotetext{
${ }^{1}$ This shift is more commonly known as Bennett's law (Bennett 1941).

${ }^{2}$ For example, Reardon, Stamoulis, and Pingali (2007) show how changes might be strongly related to geographical locations.
} 
sector, and the reliability of the justice system, among others, are important in shaping the final outcome of the chain. Policy factors also play an important role, be it regulation, hard infrastructure, institutions, international trade, or foreign direct investment (FDI) rules. ${ }^{4}$

Changes in the supply chain are ultimately transmitted to the rural producer. His or her production environment and livelihood might change due to the different crops that he or she is required to grow and due to changes in input as well as output prices. Moreover, other types of labor, land, inputs and technologies may be used, and new requirements of the market, including transaction requirements (such as postharvest handling) might translate into additional investments. The producer's behavior is, however, influenced not only by market forces but by nonpolicy conditioning factors and policy factors as well. The rural nonfarm economy will often strongly condition the ability of the farmer to make the requisite investments to respond to the requirements of the transformed supply chain (Reardon, Stamoulis, and Pingali, 2007).

The differential pull and push factors lead to a difference in food supply chains across countries and products - as reflected in different types of institutional arrangements, which range from spot market exchanges to full vertical integration, in which the stages of marketing, transaction, and production are linked through ownership rather than through market exchanges (Swinnen, 2007). These factors will also lead to a different growth path for the modern sector within the food supply chain. Better vertical coordination mechanisms might result in significant cost savings for the firms involved in the modern sector, and economies of scale could potentially lead to lower prices to the consumer, higher prices for the producer, and/or more quantity traded in the sector. However, growth might be constrained by policy factors and conditioning factors, as well as the specific structure of rural supply and urban demand (Swinnen et al., 2008).

The effects of changes in food supply chains - such as branding - on poverty are strongly debated in the literature. Minot and Roy (2007) distinguish four pathways by which they might affect poverty: through a direct effect on farm income, through backward linkages to agricultural input suppliers, by changing wages and employment, and by affecting the food prices faced by consumers.

\footnotetext{
${ }^{3}$ Increasing urbanization leads to an increasing scarcity of labor in rural areas and might, through induced innovation, force the adoption of new, less labor-intensive technologies.

${ }^{4}$ For a more detailed discussion, see Reardon and Timmer (2007).
} 
First, significant research has examined the effects of these changes on farm income. Higher standards of branding companies might lead to higher technical requirements, which in turn translate into physical investments, human capital investments, more coordination costs, and practice changes at the farm level (Reardon et al., 1999). Minot and Roy (2007) argue that the effects on smallholders in particular depend on five factors, including the relative costs of production, the relative costs of marketing, the agrarian structure, the nature of consumer demand, and the nature of marketing institutions. This theoretical differential effect is reflected in the empirical research on the impact of changes in the supply chain (for a detailed overview, see Reardon et al., 2009).

Second, a few studies have investigated the impact of changes in backward linkages. For example, Kimenye (2002) finds that high-standard green bean production has significantly higher backward linkages with input markets through the increased demand for chemical inputs, irrigation services, and so on. Hernández, Reardon, and Berdegué (2007) and Natawidjaja et al. (2007) find similar results in the cases of Guatemala and Indonesia, respectively. Changes in backward linkages could become more prevalent due to the emergence of branded products. Due to the increased demand, the organization of supply chains for inputs might improve, as urbanproduced equipment and variable inputs might become cheaper because of economies of scale (e.g., von Braun and Kennedy, 1994).

Third, some research has looked at the effect of changing food supply chains on labor markets and employment in the food supply chains or in the agricultural sector itself. Researchers have hypothesized that poverty might be reduced because of the intensive use of unskilled labor in these new supply chains. Some recent studies have found that this impact pathway can be very important in developing countries (e.g., Barron and Rello, 2000; Maertens and Swinnen, 2009; McCulloh and Ota, 2002; Jarvis and Vera-Toscano, 2004).

Fourth, food prices in rural as well as urban areas might be affected due to the transformation of the food economy. This might be partly due to changes in demand for quality as prices for products of the same quality go up due to higher demand, or higher qualities are delivered that fetch a higher price overall. Food prices might be different for branded products compared to traditional loose and unbranded products. 


\section{Background}

Makhana or gorgon nut is an aquatic crop that is largely grown in Northern India. ${ }^{5}$ Though makhana is also found in wild form in China, Japan and Russia, India is the only country where makhana is cultivated as a crop, mainly in the states of Bihar and some parts of Assam (Mishra et al., 2003). It is estimated that Bihar accounts for more than 80 percent of total makhana production in the country and that makhana production takes place in 20 out of its 38 districts. Makhana as a crop can be cultivated in any pond that is shallow and stagnant. However, localized expertise of makhana cultivation has cast doubts on its propagation beyond its traditional territory, Northern Bihar and lower Assam. Makhana has shown important production increases in the last decades and makhana cultivation has, endogenously without public research or extension intervention, spread to ricefields that in the flooded off-season can be used in some districts in Bihar for makhana cultivation. It is estimated that while makhana cultivation done in ponds accounted for $90 \%$ of total production 10 years ago, $65 \%$ and $35 \%$ of current production comes from ponds and ricefields respectively. ${ }^{6}$

In those areas where makhana cultivation is done, it is estimated that about 10 or 15 village ponds are in use. The majority of these ponds are owned by the government and leases for shortterm use are auctioned by the fishermen's cooperative society. However, a number of ponds are in private hands. Most of the cultivation is done by the malla caste (Mishra et al., 2003). Average production levels are estimated to be around 0.85 tons per acre but the highest yields can go up to 2 tons per acre. No improved varieties for makhana are currently available and higher makhana yields can only be achieved by improved pond management, especially the application of organic matter in the pond as well as irrigation.

Makhana cultivation is characterized by a strong seasonality. To avoid decline in quantities harvested, clay should regularly be removed from the ponds (usually every three or four years). This is usually done during the months of October and November. Sowing of the new crop then takes place in the months of January or February and germination happens after 30 to 40 days. In the case of commercialized makhana cultivation, young seedlings are transplanted from nurseries to the ponds or rice fields. Such transplanting, as in the case of rice, usually leads to higher

\footnotetext{
${ }^{5}$ The states of Bihar, Manipur, Orissa, Jammu and Kashmir and lower Assam.

${ }^{6}$ Personal communication, Dr. Jha, Director, Research Centre for Makhana, Dharbangha.
} 
yields. Makhana harvesting usually starts at the end of July and can go up until the end of September or the beginning of October. Harvests are often done in different intervals (up to three harvests) with the first harvest being the biggest one. The processing of the harvested makhana seeds into makhana pop might then go on until December. A pre-condition for the processing to start is that seeds need to first dry for about 10 days or so.

Makhana pop has several uses. It is a highly relished food taken as namkeen, kheer, curry, etc. (Mishra et al., 2003). Makhana further holds special importance in cultural and social life of Bihar. It is considered obligatory for brides' parents to send makhana to the house of the groom to serve the latter's family before the marriage. It is usually eaten with betel and betel nut. It is also used as a part of final rituals in case of death.

\section{Data}

\subsection{Data collection}

Surveys were implemented with funds from the National Agricultural Innovation Project (NAIP). One of the components of this project aimed to improve agricultural performance, and more particularly so in disadvantaged districts of India. Based on several indicators (agricultural productivity per worker, agricultural wage rates, and share of the scheduled caste/tribe in total population), 150 districts were thus assigned to the 'disadvantaged district' status by the Planning Commission of India. The NAIP project in Bihar had activities in four of these disadvantaged districts. The one district where makhana production was important, i.e. Darbhanga, was subsequently selected to field the surveys. It is estimated that about 30,000 to 40,000 people are involved in the makhana sector in Darbhanga. The total makhana area cultivated in Dharbangha amounted to about 1200 hectares in 2009. This compares to a total of 15,000 hectares in Bihar. Increasing commercialization has been noted over the years. While before the 2000s, only a tiny share of makhana was exported outside the district, it was estimated in 2009 that almost $60 \%$ is sent outside the district.

In preparation of the survey, we implemented extensive key informant interviews with several people in the value chain. We also had several talks with the manager of Shakti Sudha, the largest processing company of makhana as to understand their procurement, processing, and 
sales practices. The information collected in this stage helped then in the design of the survey instruments.

Different types of surveys were set up in the beginning of 2010 as to understand the value chain. They included surveys with makhana producers and a village survey, wholesale and retail trader surveys, and a processor survey. Extensive key informant interviews were conducted before the fielding of the surveys in the middle and end of 2009. The initial idea was to study the impact of direct procurement of Shakti Sudha Industries on producers in the local communities. However, despite multiple attempts with the manager of the company as well as with local traders, we were unable to track down its suppliers from the villages in the makhana producing block (Manigachi) where the company was active, inside the selected district as well as outside it. This indicated that the company did not have these downstream activities (anymore?) that it claimed to have in place earlier or, more likely, that it never had the claimed procurement practices in place at least on a large-scale. When this information was available, we followed the sample procedure as follows.

In the selected district, twelve makhana producing villages were randomly selected. In each selected village, a village questionnaire was implemented. In each selected village, a census of households was conducted to enumerate all the makhana producers. Each household was asked questions on their total area of ponds and makhana cultivation. From all the makhana cultivators, 18 households were randomly selected. For all the selected households, a detailed household survey was conducted. 217 makhana households were effectively interviewed in total, one above the target of 216 , i.e. 18 households $* 12$ villages. In each selected village, 2 makhana processors were interviewed as well.

We implemented the survey of makhana retailers in 50 colonies in the city of Patna. The city of Patna has 72 wards. Ten wards were randomly selected and then five colonies in each of those 10 wards. A complete census of retailers that were selling makhana was done in each colony. A survey was then implemented with four retailers randomly chosen from the census list. In total, we interviewed about 150 retailers, lower than targeted as in some colonies not enough retailers could be found. Simultaneously, a wholesale questionnaire was implemented with all the wholesalers in Patna (a census of the wholesalers) and in the rural production areas where the producer survey was being fielded and with a small number in Delhi. 


\subsection{Descriptive statistics}

Table 1 presents the descriptive statistics of the interviewed makhana farmers. The average age of the head of household is 49 years. Head of households are all male and $93 \%$ of the households belong to the malla caste. While some key informants indicated that other farmers than the malla caste were often cultivators of the pond while the role of the malla caste - the traditional producers and processors of makhana - was reduced to wage labor for makhana production, this is thus not borne out by our data, at least in the survey area. The size of an average household would be slightly above 7 members. Two-thirds of the producers are member of a fishermen cooperative society but only very few are members of any other farmers' organization.

The households involved in makhana cultivation are relatively poor, even for Bihar standards, as seen by several indicators (Table 1). First, $48 \%$ of the heads of households are illiterate. Second, more than two-thirds of the producers are holders of a Below the Poverty Line (BPL) or Antyodaya card, both indicators of severe poverty. Third, $60 \%$ of the producers interviewed described themselves as poorer than the average household in the village. One quarter even selfreports to be among the poorest in the village.

Table 1: Characteristics of makhana farmers

The average number of ponds cultivated by the household is 2.1 (Table 2). While almost half of the farmers only cultivate makhana in one pond, $13 \%$ of the households reported to cultivate more than 3 ponds. The average pond area cultivated per household is 4.8 acres. Further questions were then asked on makhana cultivation in the year 2009. The average production per household was 3.1 tons or about $635 \mathrm{kgs}$ per acre. Most of the marketing of makhana was done in the form of seeds and only a minority of the farmers (32\%) sells the processed makhana (popped makhana). During key informant interviews, there were regular complaints that harvesting and processing was delayed because of limited processing capacity or timely availability of labor, leading to deterioration of the product. However, that seems to be a minor problem in practice. Only $12 \%$ of the producers delayed harvesting when seeds were already ready and the average number of days that seeds were kept between harvesting and processing was 5 days. The time in between was mostly required for drying of the product. $27 \%$ of the producers evaluated that the quality of seeds deteriorated during drying. Of these, all believed 
that the quality of pop would have been better if processed earlier. More than a quarter of the producers thus seemingly suffered losses because of late processing.

Table 2 further presents information on general characteristics of the cultivated pond. About half of the ponds are located in the same village where the cultivator is living. The average area of a pond is 6.9 acres. However, the average area is high because of some large ponds in the sample, as the median area is only 2.5 acres. The average area cultivated by the interviewed household in the pond is 2.2 acres. In the majority of the ponds (64\%), there is only one cultivator per pond. An average cultivator reported one incidence of flood and one incidence of drought in the last five years (in both cases, the makhana plant cannot grow or does not reach its full potential). Few people own and cultivate a pond themselves, i.e. for only $13 \%$ of the ponds was the owner also the cultivator. $87 \%$ of the ponds were subject to a lease. However, the need of a lease did not preclude people to cultivate for a long period on the same pond, as the average years of cultivation of that pond was as high as 14 .

Table 2: Information on makhana cultivation and pond characteristics

More detailed information was then asked on the leasing process. The average length of the lease was 3.1 years (Table 3). 55\% of the ponds had a lease of 2 to 3 years. In only $4 \%$ of the cases was there a lease that was longer than 5 years. On the other side, $20 \%$ of the ponds only had a lease for that particular year of the survey. Three quarters of the farmers further indicated that the length of the lease could be extended after the current lease expired. In contrast with the general perceptions, or with situations in other districts in Bihar, leases with private owners are most prevalent and accounted for $63 \%$ of all the leases. Cooperative or government ownership was as high as $37 \%$. Only a small percentage of the farmers reported that they obtained the lease through an auction and it thus seems that most deals are settled directly one-on-one between cultivators and owners (for government ponds, the requirement is to go through auctions). In the majority of the cases, there is no family relationship between the secretary or the owner of the pond. This reflects the importance of private ponds in this area as almost all the respondents agree with the statement that you have to be a family of the secretary of the fisherman's cooperative society as to be able to obtain a lease to a government pond. This is an important finding given that rates for these government ponds are often leased much below market rates (91\% of the households agreed with that statement). Almost all farmers pay a fixed fee for the 
leasing of the pond and sharecropping is little practiced. Farmers do realize the importance of the set-up of these leases and the majority of the farmers agree with the statement that in the case that leases are longer, makhana production increases because of more care and investments in the ponds.

Table 3: General and leasing information of ponds

The average production of makhana seeds per pond was 1.57 tons in 2009 in particular (Table 4). This was about $18 \%$ lower than the expected harvest level during the cultivation period, possibly driven by incidences of floods and droughts as $12 \%$ of ponds were reported to have suffered from floods and another $12 \%$ from droughts. The Table further shows input use and technology adoption for that pond. Only a low number indicate that they practice cleaning of clay in the ponds (every three or four years). In contrast, transplanting is now widely used and more than three-quarters of the cultivators indicate that they practice transplanting of the makhana seedlings (in contrast with broadcasting). The NAIP project, through the Research Centre for Makhana, is heavily involved in not only improving makhana cultivation but also to extend better alternative income generating activities related to the pond as these can be important for the livelihoods of these farmers. Almost $40 \%$ of the makhana cultivators indicate that they also cultivate fish on top of makhana in their ponds. $8 \%$ reported that they grow fruit trees on the boundaries of the makhana ponds.

Table 4 shows that most of the monetary inputs in the production process are related to payments for labor use. These costs account for $60 \%$ of total monetary production costs. It is estimated that about 63 man-days of labor are used in a pond (except for the harvest). 53 of those days are used as hired-in labor and only 10 days are own labor. Non-labor monetary input costs amount to 3,408 Rs per pond. Three major activities account for the majority of input costs, as well as labor use, i.e. cleaning of the pond, gap-filling or thinning, and irrigation. Harvest activities are not shown in Table 4. The general practice is that harvesting is done in different intervals and that workers are paid per kilogram of seed harvested. As the quantity that is harvested is going down at each interval and as the required efforts are usually larger, the hired labor is typically paid a higher share of the harvest in the second and third round compared to the first one.

Table 4: Makhana production and input use in 2009 
Table 5 shows descriptive statistics on characteristics of the different value chain agents on top of the farmers that were interviewed in the value chain study. First, we interviewed 36 processors. The average processing capacity of these processors is about 68 tons of makhana seeds per year. Most of the processors have been doing this job for a long period, i.e. 24 years. As the job requires very specific and hard to master skills in the popping technique, processors often have to go through years of apprentice often with family members before they effectively master the skill and are able to achieve high popping rates. ${ }^{7}$ The required investments for processing are limited and investment levels are as high as 6,986 Rs (i.e. 155\$). Processors declare that they are able to achieve a conversion rate of $40 \mathrm{kgs}$ of pop out of $100 \mathrm{kgs}$ of seed. The percentage of lava, the best quality of pop, in total popped quantities is estimated at $78 \%$.

Second, 24 wholesalers were interviewed in different markets, i.e. $57 \%$ in Patna, $26 \%$ in the production areas (Dharbangha and Madhubani), and 17\% in Delhi. Wholesalers declare to procure on average about 7 tons per week in the beginning of the harvest period, i.e. July to September. This increases then to an average of about 11 tons per week in the period of January to March. Compared to the procurement numbers five years ago, we see a doubling of the procurement quantities by these wholesalers, possibly indicating the fast growth of the commercial makhana sector (as indicated by several key informants). The number of suppliers that they procure produce from also shows significantly seasonal movements, in line with the increased quantities. While the average number of suppliers is as high as 11 in the period of JulySeptember, this increases to 17 in the period January-March.

Third, 154 retailers were interviewed in the city of Patna. Only some retailers are street hawkers and most of the makahana is sold by kirana stores, i.e. mom-and-pop stores ( $97 \%$ of those interviewed). The quantities that are sold of makhana are low and amount only to $5 \mathrm{kgs}$ per day per store and stores declare that this product makes up just over $4 \%$ of their sales and profits. It is thus clearly a minor product in the sales portfolio for most of these stores. Values on asset values and working capital are shown at the bottom of the Table 5. They show that most retail stores are rather small operations, i.e. the average value of assets and working capital are evaluated at 1,100 USD and 2,600 USD respectively.

\footnotetext{
${ }^{7}$ The Research Centre for Makhana has developed a first proto type machine to allow for mechanical processing. However, the rates of popping that are achieved are significantly lower than those of manual processing.
} 
Table 5: Descriptive statistics agents value chain surveys

\section{The prevalence of branding and packing}

While seemingly little has changed on the production side, we note however important changes upstream, especially related to packing and branding practices. Table 6 shows the importance of branded and packed produce in the current sales. $96 \%$ of the interviewed wholesalers report that they are currently selling branded and packed products. Branded products now account for almost half of their total sales. This compares to only $23 \%$ five years ago. The rather recent takeoff of branded products is further illustrated by the year that these wholesalers started selling branded produce. ${ }^{8}$ While almost all wholesalers are selling branded products now, only $27 \%$ was doing so before 2004. A large number of wholesalers (45\%) started selling branded products in the years 2004-2005, the apparent year of major take-off. There is thus a fast emergence of these branded products in this sector and this begs the question on how this branding process works in practice. Wholesalers were asked on the importance of branded products in their sales as well as in their procurement. The numbers show that branded products are twice as important in sales as in procurement, indicating that a large part of the branding is done by these interviewed wholesalers themselves. However, it also indicates that at least some wholesalers buy branded products and then re-sell them.

Table 6: Importance and emergence of branding as reported by wholesalers

Wholesalers were asked further detailed questions on each branded product that they were selling at the time of the survey (Table 7). Despite the rather small market and the recent start of brands, the results show that there are a large number of brands out there. 33 brand names were found in total. There are no clear large market leaders and the most frequent observed brand, Swagat, accounted for only $13 \%$ of all the brands found. ${ }^{9}$ Of all the brands on sale, $31 \%$ were packed by the wholesalers themselves and a quarter of the branded bags were sold exclusively by that wholesaler.

The bags contain in general $250 \mathrm{mgs}$ of popped makhana (97\% of the brands). The type of makhana found in the bag is usually a mix of qualities and in only a few cases, it is indicated that

\footnotetext{
${ }^{8}$ This statistic was only calculated for those wholesalers that had been in business for a long enough period.

${ }^{9}$ Ramaswami et al. (2009) found similar results in the proliferation of brands in cotton seed markets in India.
} 
only the best quality ('lava') is in the bag ( $9 \%$ of the bags). Quality assurance is often done at the level of the wholesaler himself (35\%). There is not clear homogeneity in the quality per bag. While $48 \%$ of the same brands are reported to show no difference in quality, $38 \%$ and $13 \%$ show 'a bit' and 'a lot' of difference in quality respectively. Further information was asked on the information given on the bag. In $80 \%$ of the brands, the exact weights were printed on the bags. However, most other information that typically goes with branding was not available. Only $16 \%$ of the bags provided an expiry date. In none of the cases, the exact address of the manufacturer or the maximum retail price was printed. In $5 \%$ of the cases, the telephone number of the manufacturer was given. In case a customer was thus not satisfied with the product, it would be hard for him to trace back the company where the product was made.

Table 7: Description branding practices

\section{Market structure}

In traditional makhana markets, four quality types of pop are distinguished, i.e. lava, murha, turi, and mix. The differences in quality are almost exclusively linked with the size of the pop.

Makhana transactions in these traditional markets are done in gunny bags. These gunny bags are standardized in size and the weight of such a gunny bag is indicative of the quality of makhana. If makhana is processed well, makhana pops are larger and weigh less and a low weight of a bag is thus an indication of good quality. The general rule of thumb is that a bag of $8 \mathrm{kgs}$ is an indication of high-quality lava makhana and a bag that weighs more than $10 \mathrm{kgs}$ contains mostly lower quality makhana.

The previous section has shown how the branded products done by wholesalers themselves have taken off in recent years. We will call this the low-cost branding from here onwards. Table 8 documents some of the costs and benefits from this branding process for the wholesalers that do so. Different activities are needed to do the packing and branding process. They involve the purchase of designed bags and bagging. Half of the wholesalers buy empty branded bags. While some of these bags are made in the production area Dharbangha itself, the majority however are ordered from specialized manufacturers in the cities of Kanpur or Delhi. In 18\% of the cases, the design of the bag was done by the wholesaler himself. If not, the costs of the (outsourced) design amount to a one-off investment of $22,000 \mathrm{Rs}$. The average cost per empty bag is $2.1 \mathrm{Rs}$. Almost 
half of the wholesalers (47\%) report to own a packaging machine. The investment costs of such a machine are minimal as the reported price is 1,862 Rs (or 41 USD). The labor costs involved in filling up and the sealing of the bags amounts to 0.4 Rs. The overall variable costs for packing are thus $2.5 \mathrm{Rs}$ per bag or $10 \mathrm{Rs}$ per $\mathrm{kg}$ (as bags are mostly $0.25 \mathrm{~kg}$ ). Wholesalers were asked at their level to evaluate the benefits from the packing and branding process. They estimated that if the products that were in the bags were sold loose, they would be able to obtain a price that is on average 15 Rs lower than when bagged and branded. ${ }^{10}$ However, some wholesalers indicated that these products were not comparable as the quality of products that go in the branded bags is low and could not be sold loose.

Table 8: Cost and profit analysis of branding, traditional wholesalers

In the opinion of the wholesalers, branded bags do not contain quality that is better than those products that are sold loose (Table 9). 19\% of the wholesalers indicate that the quality of makhana in the branded bags is better, $38 \%$ evaluates the quality to be the same and $38 \%$ thinks it is worse. Most of the wholesalers also indicate that the quality of the makhana that is used for inclusion in the bags can come from all types of suppliers (58\%) and inclusion in the bag does not depend on specific characteristics of suppliers. There are thus seemingly little exclusion effects from branding, as those that have sometimes been found in other modernizing markets (e.g. Reardon et al., 2009). None of the wholesalers that produce the branded bags employ salesmen to sell their brand and none pay for ads on television, on the radio or in the newspaper.

Wholesalers were further asked questions on why they do not sell more branded products. The major reason is seemingly that a large number of customers like to check the quality of the product and they cannot do this with the packed product. The lack of demand for branded product does not seem related to the higher prices that are asked for branded products ( $5 \%$ of wholesalers), the longer time required to sell branded products (11\% of wholesalers), and the lack of availability of sufficient quality to be included in branded bags ( $6 \%$ of wholesalers).

Table 9: Branding and packing, as reported by wholesalers

\footnotetext{
${ }^{10}$ Wholesalers indicated that they use a differential price scheme where higher prices were asked from direct consumers that bought from them compared to purchases by retailers. The average price difference was about 8 $\mathrm{Rs} / \mathrm{bag}$ or $32 \mathrm{Rs}$ per kg. However, direct sales to consumers are limited.
} 
A different packing and branding system has been put in place by Sudha Shakti Industries which has received significant positive reports. ${ }^{11}$ We will call this the high-cost brand hence forward. This firm which started in 2004 implemented a new business model opening up new market opportunities for the makhana product. While the best quality of makhana (lava) is branded and sold in export markets or in big cities, the lower qualities are processed into new products, such as roasted snack foods, flakes or powder for pudding. These products did not exist in the market place before. To sell the branded products, they employs 24 sales persons in the country and they spend on average 1 million Rs (22,000 USD) for ads on TV, on the radio and in newspapers. The reported quantities of popped makhana sold by the company have increased from 124 tons in 2005 to 3,000 tons in 2009. Of the 3,000 tons in 2009, 40\% was sold in export markets (mostly to Pakistan, Nepal, Bangladesh, and the Middle East; no processed products were exported) while the rest was being sold in local markets all over India (30\% sold as processed products and $70 \%$ in natural from). Little is sold to local markets in Bihar as they feel there is no quality demand and quality rewards in these local markets.

Sudha Shakti Industries implemented a procurement system that supposedly benefits the farmers in four ways. First, they assure a fixed floor price at $100 \mathrm{Rs} / \mathrm{kg}$ for makhana pop. A different price is implemented every month in line with market prices but farm prices can never drop lower than this floor price. Farmers are paid within 3 days of delivery in their account. Second, farmers are linked to the banking system and are required by the company to set up a banking account. They will help farmers then get access to the Kisan Credit Card scheme, a successful government intervention that allows farmers access to (cheap) credit. Third, farmers do not have to bear the cost of transportation as this is re-imbursed by the firm for all produce that is transported from farmers' fields to collection centers. Fourth, Sudha Shakti Industries facilitate the leasing arrangements between cultivators and owners of ponds (mostly linking the owners of ponds to potential cultivators as well as the writing of contracts). However, despite a large number of interactions with Sudha Shakti Industries as well as with key informants in several of their supposed production areas, only a handful of people could be identified that had direct

\footnotetext{
${ }^{11}$ Business Outlook, a leading Indian business magazine, has chosen it one of the 14 best agricultural innovations in the country (http://business.outlookindia.com/inner.aspx ?articleid=2165\&editionid=58\&catgid=2\&subcatgid=973). The World Bank (2007) indicates that the activities of the firm have led to a "white ball revolution" in the state of Bihar.
} 
linkages with Sudha Shakti Industries and it seems that their direct procurement model has (mostly) fallen apart in recent years (and they might procure part of their products from traders).

To evaluate the quality that is sold by the branding companies, bags of the high-cost brand (Sudha Shakti Industries) and of a prominent low-cost brand were bought and opened. Produce was taken out and shown to the wholesalers without them knowing where the product came from. In an open-format question, wholesalers were asked to state what the maximum price was that they were willing to pay for that makhana quality. The results shown at the bottom of Table 8 shows that the wholesalers valued the makhana quality that was contained in the high-cost brand at a higher price than the low-cost brand. The difference between the two qualities was 16 $\mathrm{Rs} / \mathrm{kg}$ indicating the higher quality in the high-cost brand. In a one-sided t-test, this difference is significant at the $10 \%$ level.

\section{The benefits of packing and branding}

To understand the effect of branding and packing on rewards in retail markets, price data were collected for all makhana products (loose, packaged, and branded) that were being sold by makhana retailers in Patna. Information was also collected on the size of the pop and the location of the sale (kirana stores as well as the specific ward and colony). The results of a hedonic price regression including these variables are reported in Table 10. The logarithm of the price of makhana in Rs per $\mathrm{kg}$ is used as the dependent variable. Ward and colony dummies are included in all specifications as to control for possible location-wise unobserved heterogeneity. Two models are estimated, i.e. a model where brand and packaged are included together, and a specification where the brand and packed dummy are interacted.

The results show that the lava quality (the default value in the regression) is rewarded with a premium of between $7 \%$ and $11 \%$ in the market place, compared to a mixed quality. The coefficients come out significant in both specifications. The rewards of the lava quality compared to the murha variety are not significant at conventional statistical levels. However, there were only a few murha observations in our dataset and comparison is a bit difficult. Makhana products sold in kirana shops are on average, controlling for confounding factors, not cheaper than those sold by street hawkers. 
The regression results show the significant rewards to branding and packing in retail markets, in both specifications. Packaged products are sold at prices that are $9 \%$ higher and branding adds another $9 \%$ on top of this (model 1). A dummy that includes only packaged and branded products show that, controlling for location and quality, prices for such branded/packed products are about $15 \%$ higher than the price of the other products.

Table 10: Price effects of branding in the retail market

We thus find significant price effects of branding in the retail market. It is still not clear how the branding effects works in practice and a number of questions were thus asked on this to the retailers (Table 11). While almost all wholesalers sell branded products, their importance is much less in retail market of Patna (19\% of retailers sell branded products), probably indicating that a large number of the branded bags handled by wholesalers in the city are sold outside Patna (and mostly in bigger cities outside the state). For those retailers that sell branded products, they almost exclusively sell branded products as they account for an important percentage in total sales for these retailers (92\%). In contrast with wholesalers (who better know what actually goes into the bags), the majority of makhana retailers that sell branded products believe that the quality of these branded products is higher (73\%). $90 \%$ of the retailers also report that prices are higher than for loose products, confirming our quantitative results.

Retailers were then asked to evaluate why they think consumers are interested in branded products. All retailers believe that because of the branding, customers are assured of receiving the right quantity of the product. Only just over half of the retailers believe that customers would buy brands because of better quality. Retailers that were selling branded products were asked qualitatively to state why they were selling these branded products. Only a small number indicated that this was done because of higher profits but they prefer the branded products because of a reduction in hassle (as no weighing and quality checking by customers was required) and because of the increase in demand for these branded products by customers. When asked on the type of customers that would buy these branded products, the majority of retailers indicated that they were richer customers $(68 \%)$ than those buying loose products.

Table 11: Perceived impacts of branding, as reported by the retailers 


\section{Do producers benefit from branding?}

To understand the importance of different agents in each supply chain, detailed marketing and price questions were collected at each level. Farmers were asked to give specifics on the marketing of their makhana and for all transactions done in the last year, they were asked details on relevant marketing information. The results of these are reported in Table 12. An average transaction at the farm level concerns 1.2 tons of makhana sold for a total value of $62,458 \mathrm{Rs}$ (about 1,400 USD). Most of the makhana sold by farmers is marketed under the form of makhana seeds (55\% of the transactions). $44 \%$ is sold in the form of mixed popped makhana and in only $1 \%$ of transactions is popped makhana sold as makhana lava. The grading in different qualities is thus seemingly happening at a later stage than the farmer level. In our interviews with farmers, they indicated that they preferred to sell mixed qualities as it is reportedly hard to grade and get rid of the lower popped quality makhana in the market place. Results indicate that price for popped makhana are more than 2.5 times higher than makhana seeds, reflecting the processing conversion ratios as well as payments to processors.

Most of the sales of makhana happen in a short-time period and it seems that few farmers store makhana as to benefit from the (potentially) higher prices that might be offered in the off-season. $56 \%$ of all transactions happened in the months of August and September and only 3\% of the transactions were reported to have happened during the off-season of January until April. More than half of the transactions (51\%) are done with collectors in the village and 20\% with wholesalers from the district itself while in $13 \%$ of the cases, products are sold to processors, indicating their importance as an important marketing outlet for some farmers. Major reported reasons for the choice for a specific buyer are related to immediate payments (52\% of the transactions) and proximity of the buyer (20\% of the transactions). Surprisingly, 'high prices' came only third (18\% of the transactions).

Despite our efforts to field our surveys in areas where the Shakti Sudha Industries were active, only $0.3 \%$ of the transactions were reported to have been done with them. The majority of transactions are done in cash and in the village of the farmer. Farmers would travel on average 8 kilometers and the time required between the departure from home and the arrival at the sales' location would on average be 0.5 hours. Transaction time at the sales location was more important and evaluated at almost 2 hours. In almost $80 \%$ of the cases, transactions were paid on 
the day of the delivery and in contrast with conventional wisdom, input advances are not very important as in only $3 \%$ of the transactions, input advances were reported to have been given by the buyer of the produce.

Table 12: Marketing by makhana farmers (\% of transactions)

Using regression analysis, Table 13 shows the importance of different determinants in price setting at the farm level. ${ }^{12}$ They show the rewards, as could be expected, from the sales of processed makhana compared to makhana seeds. The results also show that makhana lava is sold at a premium over mixed quality of $17 \mathrm{Rs} / \mathrm{kg}$ on average during the year of the survey. There are few other determinants that show a significant effect on the price. Prices go up when farmers are able to offer a higher quantity. A doubling of the quantity sold leads to a price offered that is about $1 \mathrm{Rs} / \mathrm{kg}$ higher. Unexpectedly, makhana sold to wholesalers from the district itself fetch a lower price than products sold in the village itself. Most importantly, the results show that the high-cost brand in the case that they were directly procuring from the farmer, were able to offer a price to the farmer that was significantly higher than any other procurement outlet. So, some farmers benefited from their procurement model. However, as shown in the previous section, the procurement by them has been limited in the year of the survey.

Table 13: Price determinants farm prices

Based on price data collected in the different surveys with all makhana value chain agents, we are able to calculate the relative contribution of each actor in the final retail price. We present this graph for loose as well as branded products during the period July-August 2009. To make prices comparable, the reported makhana seed prices (the most common form under which farmer market makhana) was converted to pop equivalents by using a conversion ratio of $40 \%$ (coming out the of the survey). As margins were not collected at the same period for wholesalers and retailers, margin rates from the period asked for were imposed to the other period. The results are shown in Figure 2.

The results show that the farmers receive $55 \%$ of the final retail price in Patna, in the case that makhana is sold loose. As there are no benefits to the farmer of the branding process, this share

\footnotetext{
${ }^{12}$ Standard errors of the regression coefficients are estimated after accounting for within cluster (village) correlations.
} 
declines to $50 \%$ in the case of the final price for branded products. In both cases, farmers are thus the agent in the value chain that gets most of the rewards, reflecting also most of his effort for the product. As is usual the case in these markets, the retail margin is the second most important component in the final price, accounting for $19 \%$ and $22 \%$ in the final retail price of loose and branded products respectively. Processors and urban wholesalers count for equal shares in the final retail price.

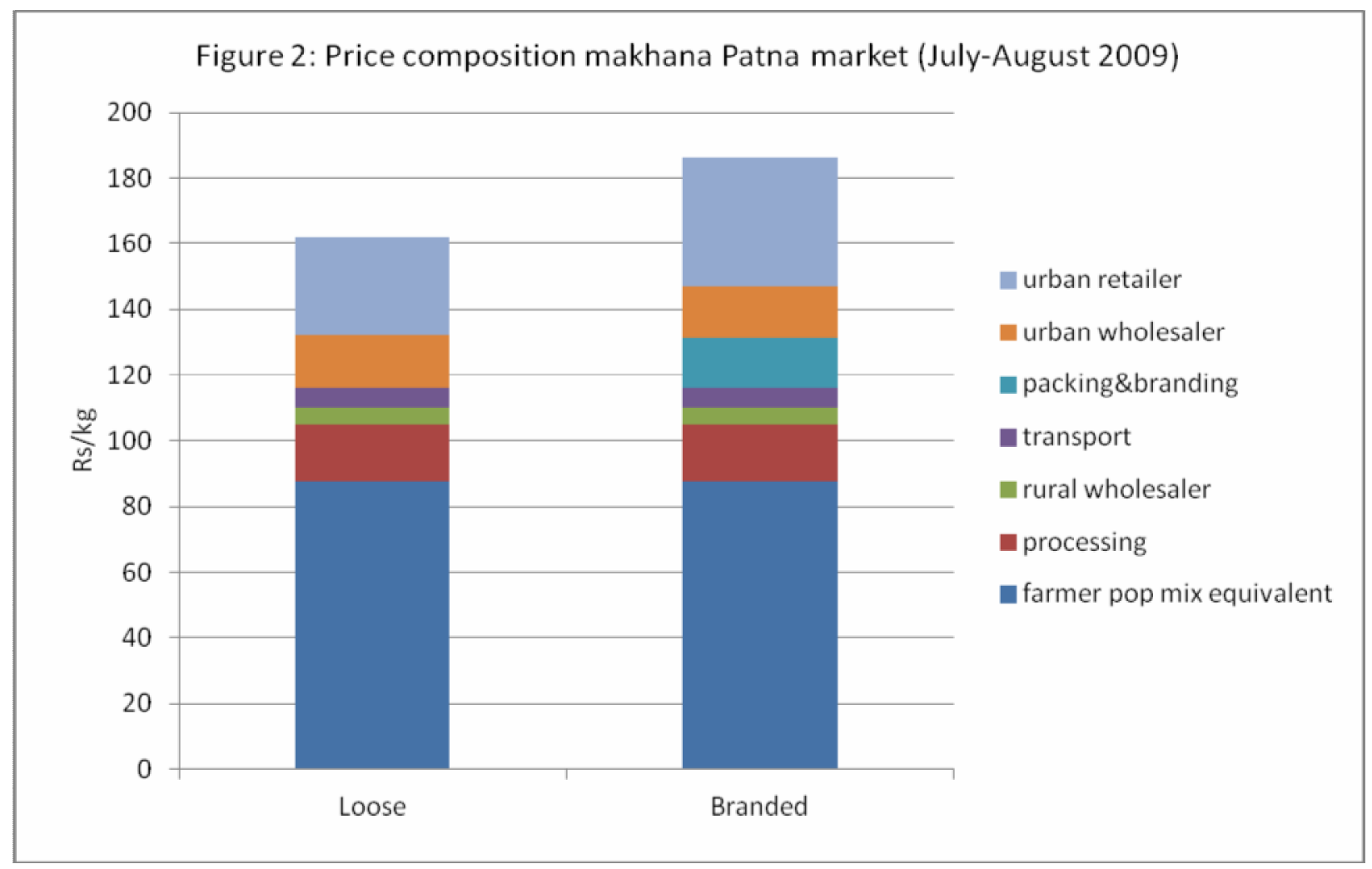

\section{Conclusions}

In response to growing incomes, developing countries see increasing differentiation and choice in their food retail markets. However, it is not well understood what these choices entail in these transitional markets. In a detailed case study of makhana in Bihar, we see the fast emergence of more expensive packaged and branded products. Two types of brands can be distinguished, i.e. low-cost and high-cost brands. Low-costs brands focus exclusively on attractive glossy packing with little consideration for quality. Investments, but profits as well, are small. The high-cost brands pay attention to quality beyond packing, invest in advertisements and promotion, explore options for value-addition, and employ specialized salesmen. We find that there are little direct 
benefits to the farmers from the emergence of these brands. However, farmers might benefit indirectly because of the expanding product demand.

The research indicates to several policy implications. First, it might indicate the importance of regulatory institutions and effective implementations of those as well as independent certification mechanisms. Several claims done by branding and packing institutions in Bihar are clearly false, i.e. claims are made about export quality while no export quality grades exist; claims are made about approval by research organizations while no such approvals exist; claims are made by the largest branding company on backward linkages while few of such backward linkages exist in practice. The lack of a consumer protection body or any effective regulations in this area leads thus to mis-information of consumers.

Second, there are major differences with branding practices in other sectors and countries. ${ }^{13}$ No information on the manufacturers is available on the packing of the branding companies implying that companies are not accountable for their products given consumers can not trace back deficient products in the case of defaults. We also find that the quality of branded products, especially for the low-cost brands, is often lower than loose products in these transitional markets. In contrast with regular branding practices, a significant number of brands thus try to hide bad quality inside. Brands in this setting in India thus seemingly have little function except the packing function and signal little credible information to the consumer on other characteristics of the product. While there is little role for the public sector on this, it seems possible that most of these branding practices might disappear over time as consumers become more demanding and informed.

Third, no improved varieties of makhana are currently available and the Indian research institute has only recently tried to set up research as to develop improved makhana varieties. Given the important market opportunities that exist and given that makhana is mostly grown by poor and vulnerable households in flood-prone production areas, there seems to be an important positive, and pro-poor, return to public investments in the development of improved varieties for pond cultivation.

\footnotetext{
13 e.g. Berges-Sennou et al., 2004; Carriquiry and Babcock, 2007; Jekanowski et al., 2007; Marsden and Smith, 2005; Ménard and Klein, 2004; Papadopoulos, 2004; Ponte, 2002; Ward et al., 1985; Wohlgenant, 1993.
} 
Fourth, due to the increased demand, makhana cultivation has endogenously diffused to flooded ricefields in the off-season. This might involve important new opportunities for increased production and seasonal income smoothening for rice farmers situated in these flooded areas. As most research has until now focused on pond cultivation, it thus seems important to better understand these systems and develop improved technologies for these types of production environments taking into account their specific constraints.

Fifth, leasing arrangements seem to be hampered by important governance problems and the implementation of better auctions systems and longer leases seem called for as to ensure transparency in the allocations of these leases as well as to ensure better investments because of more secure property rights towards higher productivity of the ponds. 


\section{References}

Anholt, S. (2005), Brand new justice: How branding places and products can help the developing world, Elsevier Butterworth-Heinemann, Oxford

Barron, M.A., Rello, F. (2000), The impact of the tomato agroindustry on the rural poor in Mexico. Agricultural Economics 23:289-297.

Bennett, M.K. (1941), International contrasts in food consumption. Geographical Review 31:365-374.

Berges-Sennou, F., Bontems, P., Réquillart, V. (2004), Economics of Private Labels: A Survey of Literature, Journal of Agricultural and Food Industrial Organization, 2 (3):1-23

Carriquiry, M., Babcock, B.A. (2007), Reputations, market structure, and the choice of quality assurance in the food industry, American Journal of Agricultural Economics, 89(1): 12-23

Delgado, C.L., Narrod, C.A., Tiongco, M. (2008), Determinants and implications of the growing scale of livestock farms in four fast-growing developing countries, Research Report 157. Washington, D.C. International Food Policy Research Institute (IFPRI)

Gulati, A., Minot, N., Delgado, C., Bora, S. (2007), Growth in High-Value Agriculture in Asia and the Emergence of Vertical Links with Farmers, In: Swinnen, J.F.M. (ed). Global Supply Chains, Standards and the Poor. CABI Publishing, Oxford.

Hernández, R., Reardon, T., Berdegué, J.A. (2007), Supermarkets, wholesalers, and tomato growers in Guatemala. Agricultural Economics 36(3): 281-290.

Jarvis, L.S., Vera-Toscano, E. (2004), The impact of Chilean fruit sector development on female employment and household income. Working Paper No. 04-002. Davis, CA: Department of Agricultural and Resource Economics, University of California, Davis.

Jekanowski, M.D., Williams, D.R., Scheik, W.A. (2000), Consumers' Willingness to Purchase Locally Produced Agricultural Products: An Analysis of an Indiana Survey, Agricultural and Resource Economics Review, 29(8): 43-53

Kimenye, L. (2002), Promoting farm/non-farm linkages: A case study of French bean processing in Kenya. In Promoting farm/non-farm linkages for rural development: Case studies from Africa and Latin America, ed. B. Davis, T. Reardon, K. Stamoulis, and P. Winter. Rome: Food and Agriculture Organization of the United Nations.

Maertens, M., Swinnen, J.F.M. (2009), Trade, standards and poverty: Evidence from Senegal. World Development 37(1): 161-178.

Marsden, T., Smith, E. (2005), Ecological entrepreneurship: Sustainable development in local communities through quality food production and local branding, Geoforum, 36(4): 440-451

McCulloh, N., Ota, M. (2002), Export horticulture and poverty in Kenya. IDS Working Paper 174. Sussex, UK: Institute for Development Studies.

Ménard, C., Klein, P.G. (2004), Organizational issues in the Agri-food Sector: Towards a comparative approach, American Journal of Agricultural Economics, 86(3): 770-775 
Minot, N., Roy, D. (2007), Impact of high-value agriculture and modern marketing channels on poverty: An analytical framework. Mimeo, International Food Policy Research Institute, Washington, DC

Minten, B., Reardon, T., Sutradhar, R. (2010), Food prices and modern retail: The case of Delhi, World Development, 38(12): 1775-1787

Minten, B., Reardon, T., Chen, K. (2010), The quiet revolution in "traditional" agricultural value chains: Evidence from staple food supply to four megacities, mimeo

Mishra, R.K., Jha, V., Dehadrai, P.V. (2003), Makhana, Indian Council of Agricultural Research, New Delhi

Natawidjaja, R., T. Reardon, and S. Shetty, with T.I. Noor, T. Perdana, E. Rasmikayati, S. Bachri, and R. Hernandez (2007), Horticultural producers and supermarket development in Indonesia. UNPAD/MSU Report No. 38543. Jakarta: World Bank/Indonesia.

Papadopoulos, N. (2004), Place branding: Evolution, meaning and implications, Place branding, 1(1): $36-49$

Pingali, P. (2007), Westernization of Asian diets and the transformation of food systems: Implications for research and policy, Food Policy, 32(3): 281-298

Ponte, S. (2002), The 'Latte Revolution'? Regulation, markets and consumption in the global coffee chain, World Development, 30(7): 1099-1122

Ramaswami, Bharat; Murugkar, Milind; and Shelar, Mahesh (2009) "Product Proliferation in India's Cotton Seed Market: Are There Too Many Varieties?," Journal of Agricultural \& Food Industrial Organization: Vol. 7 : Iss. 1, Article 2.

Reardon, T., Codron, J.-M., Busch, L., Bingen, J., Harris, C. (1999), Global change in agrifood grades and standards: Agribusiness strategic responses in developing countries. International Food and Agribusiness Management Review 2(3/4): 421-435.

Reardon, T., Timmer, C.P. (2007). Transformation of Markets for Agricultural Output in Developing Countries Since 1950: How Has Thinking Changed? In R.E. Evenson, \& P. Pingali (Eds). Handbook of Agricultural Economics, 3: Agricultural Development: Farmers, Farm Production and Farm Markets (pp. 2808-2855). Amsterdam: Elsevier Press.

Reardon T, Timmer CP, Barrett CB, Berdegue JA (2003), The Rise of Supermarkets in Africa, Asia, and Latin America, American Journal of Agricultural Economics, 85 (5): 1140-1146.

Reardon, T., Barrett, C., Berdegué, J., Swinnen, J.F.M. (2009). "Agrifood Industry

Transformation and Small Farmers in Developing Countries," World Development, 37(11):17171727.

Reardon, T., Stamoulis, K., Pingali, P. (2007), Rural nonfarm employment in developing countries in an era of globalization. Agricultural Economics 37(s1): 173-183.

Reardon, T., Timmer, C.P., Minten, B. (2010), Supermarket revolution in Asia and emerging development strategies to include small farmers, Proceedings of the National Academy of Sciences (PNAS), As published ahead of print December 6, 2010, doi:10.1073/pnas.1003160108, http://www.pnas.org/citmgr?gca=pnas;1003160108v1 
Swinnen, J. (2007), Global supply chains, standards and the poor. Wallingford, UK: CABI Publishing.

Swinnen, J., Rozelle, S., Xiang, T., Vandemoortele, T. (2008), A theory of standards-driven rural development. LICOS Discussion Paper 199/2008. Leuven, Belgium: KULeuven.

Swinnen, J.F.M., Vandeplas, A. (2010), Market power and rents in global supply chains, Agricultural Economics, 41(s1): 109-120.

von Braun, J., Kennedy, E. (1994), Agricultural commercialization, economic development and nutrition. Baltimore: Johns Hopkins University Press.

Ward, R.W., Chang, J., Thompson, S. (1985), Commodity advertising: Theoretical issues relating to generic and brand promotions, Agribusiness, 1(4): 269-276

Wohlgenant, M.K. (1993), Distributions of gains from research and promotion in multi-stage production systems: The case of the US beef and pork industries, American Journal of Agricultural and Resource Economics, 75(4): 642-651

World Bank (2007), Bihar agriculture: Building on emerging models of "success", Agriculture and Rural Development Sector Unit, South Asian Region, Discussion Paper Series, Report No.4, Washington DC

World Bank (2005), Bihar: Towards a Development Strategy, Washington DC 